\title{
Syntactic Errors of Foreign Speakers in Learning Indonesian: A Case Study of Darmasiswa Learning Process in Semarang City
}

\author{
Mujid F Amin ${ }^{1}$, Suyanto Suyanto ${ }^{2}$, and Fajrul Falah ${ }^{3}$ \\ ${ }^{1,2,3}$ Linguistics Department, Faculty of Humanities, Diponegoro University, Semarang, Indonesia
}

\begin{abstract}
This research was conducted in the city of Semarang with a case study of Diponegoro University. The study shows that a syntax error in the form of a sentence is not complete, the use of the word di mana (which) it is not appropriate, the construction preposition owner, the use of the word yang (that), the error sequence of words, sentences without a subject and object, misuse of conjunctions and prepositions, improper use of the passive or active voice, foreign language interference, and misuse of pronouns. The factors causing the error are the influence of the mother tongue, the limited repertoire of the students, and the lack of practice in speaking and writing in Indonesian. To overcome these obstacles, a curriculum design that emphasizes language skills is required; accompanied by Semester Learning Plans for all learning subjects along with textbooks and the learning methods used are emphasized on communication skills. An Indonesian language learning process for foreign speakers will be more successful if it involves environmental, cultural, and local wisdom factors that are carried out in an integrated manner.
\end{abstract}

\section{Introduction}

In the last decade, Indonesian has been much needed by foreign speakers. This can be seen more and more. The opening of many institutions that teach Indonesian as a foreign language both in Indonesia and in Indonesia overseas. Since 2005, 45 public and private universities have organized the Darmasiswa Program, an Indonesian language learning program for foreign speakers of the Ministry of Education and Culture. History, Indonesian language learning for foreign speakers, has been implemented since the 1970s [1]. In the city Semarang, there are at least five universities that organize darmasiswa program, namely Diponegoro University (Undip), Universitas PGRI Semarang (UPGRIS), Semarang State University (Unnes), Sultan Islamic University Agung (Unissula), and Kalolik University (Unika) Soegiyapranata [2]. The purpose of learning Indonesian as a foreign language cannot be automatically achieved because there are many problems faced in the learning process. One of the problems is language errors by foreign speakers who are learning Indonesian. If these kinds of errors are not resolved immediately, they will result in errors sustainable in the learning process, which results in not achieving the learning objectives.

*Corresponding author: mujid70@gmail.com 
Second language acquisition theory is part of theoretical linguistics because of its abstract nature [3]. In second language teaching, which is practical, is a good theory of language acquisition. The term language acquisition is used to discuss first language acquisition among children because the process occurs unconsciously, while second language learning is carried out consciously. In children, errors are corrected by the environment informally, whereas, in adults learning a foreign language, mistakes are corrected by practising reset. Language errors can be grouped into two types, namely open errors and closed errors. Open errors are language errors at the grammatical level seen in the sentence learner-generated. The closed error is an error that is hidden behind the sentence arranged correctly according to grammar but not semantically correct. Because a foreign speaker has a language error in learning Indonesian, the researcher is interested in further examining the problem of incredibly open errors at the syntactic level. By identifying these errors and explaining the factors causing the error, then the stages of learning can be determined.

Learning Indonesian for foreign speakers also needs to consider environmental, cultural, and local wisdom factors. These must be taught and studied in an integrative way with language skills to accelerate their mastery of the Indonesian language they are learning.

\section{Theoritical Framework}

\subsection{Types of errors and symptoms of language}

Deviations can be divided into three, namely error, mistake, and lapse [4]. Error is systematic and continuous language deviation resulting from not mastering the norms or norms of the target language. A mistake occurs when a learner does not consistently make deviations in language. Sometimes learners can use the rules/norms that are correct, but sometimes they make mistakes by using wrong rules and forms. Laps (skid tongue) is a form of deviation caused by the learner's lack of concentration, low memory or other causes that can occur at any time and to anyone.

Meanwhile, there are three types of writing errors that foreign learners make when they write essays. These errors include (1) mistakes in choosing words to represent concepts, (2) errors in spelling fields, and (3) grammatical errors consisting of affix errors, active-passive errors [5]. Conjunction errors and prepositions, as well as sentence structure errors. He proposed two steps of problem-solving, (1) discuss the mistakes together with the period, and (2) give practice finding mistakes in a paragraph. However, this research has not led to the learner's background and problem-solving comprehensive.

\subsection{Factors that cause language errors}

In general, it describes the problems experienced by foreign learners in learning Indonesian. First, the form of individual classes and classical classes often cause problems for learners. This is due to the learners' initial abilities of the target language/destination language are not the same, so there is an imbalance of ability in the classroom. Second, learning materials not by the level of language mastery and background behind the learner create difficulties in understanding it. Third, the teaching method is improper use in learning. Fourth, the teaching qualifications are relatively low, and the problem fifth is the administration of courses that are not "well-organized". These five problems lead to language learning in Indonesia being less effective, and achieving its goals is less than optimal [6].

In addition, the cause of foreign speakers' errors in learning Indonesian is a significant factor that comes from the learner (foreign speakers), namely the influence of the mother tongue, the lack of mastery of language rules Indonesia, and limited mastery of Indonesian 
vocabulary (repertoire). The first mistake is an error that teachers often tolerate because they come from various countries with their mother tongue so that it is quite difficult to break away from the bonds of their mother tongue. Massive error this result is at the phonological level. For example, foreign speakers with a background in their mother tongue, Japanese, cannot pronounce the sound [ $l]$ like in the word lagi (anymore), so it becomes [ragi], and this gives rise to significant differences in meaning. Such differences are no longer phonetic, that is, differences that are not meaningful, but it is a phonemic difference that gives rise to a significant difference in meaning.

Another cause of the error is that foreign speakers have not mastered the rules of the Indonesian language, so they are often conventions his mother tongue is applied when speaking Indonesian. Indonesian is a language that follows a legal pattern DM (diterangkanmenerangkan-explained and explained), which is the opposite of the languages in Europe. Therefore, speakers or learners from Europe often apply the rules of the language, MD, in speaking Indonesian. Another mistake foreign speakers make in speaking Indonesian is the limited repertoire (vocabulary) of Indonesian. This is a common symptom for current learners who learn a second language or foreign language. For one example, "Maaf saya terlambat karena berangkat dari Kampus jam 11" ("Sorry I am late because I left campus at 11 o'clock"). In the speech, the word berangkat 'depart' is meant to return home, but because of limitations mastery of Indonesian vocabulary and rules, the word chosen depart [7].

Meanwhile, Wibowo [8] shows that the learning process, in general, is still a grammartranslation method, even though all three emphasized that learning uses a communicative approach. In addition, the teaching materials have not been prepared well, so that each teacher interprets differently about the material and development. Another finding is that teachers are still trapped in using the learners' mother tongue (speakers foreign) or international languages. This slows down the mastery of Indonesian by foreign speakers.

\subsection{Syntax and effective sentences}

Syntax comes from Greek, namely, sun, which means 'to organize' and tattein, which means 'simultaneously' [9]. Syntax means arranging words together into groups of words or sentences. Ramlan [10] explains in more detail that syntax is a branch of linguistics that discusses the intricacies of discourse, sentences, clauses and phrases.

On the other hand, Santoso [11] stated that discourse is not part of syntax because it is usually discussed in a separate study called discourse analysis. This is also emphasized by Muliono [12] that syntax is a study of the rule of word combinations into larger units, namely phrases, clauses, and sentences. Thus, to understand syntax, it is necessary to understand these units.

A word is a morpheme or combination of morphemes considered the smallest unit that is pronounced as free form [13]. Meanwhile, a phrase is a language unit consisting of two or more words that do not exceed the limit of a function. A clause is a grammatical unit consisting of a predicate, whether or not it is accompanied by a subject, object, complement, and description. Meanwhile, a sentence is a grammatical unit limited by a long pause accompanied by a decreasing or rising final tone [11]. Manaf also emphasized that what distinguishes clauses and sentences is the final intonation at the end of the language unit [14].

According to Alwi [12], sentences can be divided into four types based on their syntactic form: news, command, interrogative, and exclamation sentences. Based on the number of clauses, sentences are divided into single sentences and compound sentences. Meanwhile, based on the way of expression, sentences are divided into direct and indirect sentences.

In addition to these types of sentences, effective sentences are also known, namely sentences that can express ideas expected by the writer or speaker [15]. The effective sentence must meet several conditions: clarity of sentence ideas related to the grammatical 
nature of the sentence; cohesion of sentence elements related to the arrangement of sentence elements; accuracy-related to word choice, word or phrase formation, and logical reasoning; and variety related to efforts to produce good and not boring information power [12].

Previous research related to this research was conducted by Munawaroh (1996) with the title "Writing Errors Made by Foreign Speakers in Learning Indonesian", Wibowo (2005) entitled "Comparative Study of Indonesian Language Teaching for Foreign Speakers (BIPA) in Yogyakarta", and Indrariani (2008) entitled "Verbal Behavior between Lecturers and Foreign Students in Indonesian Language Learning Interaction".

\section{Research Methods}

This research was conducted at various universities that organize Darmasiswa Program in Semarang City, namely Undip, UPGRIS, Unnes, Unissula, and Unika Soegiyapranata. Undip was determined as an institution sample. A sampling of this study using existential and purposive techniques [16]. The data to be obtained in this study are secondary data and primary data. Secondary data were obtained from the Ministry of Education and Culture and Undip. Primary data collection methods: non-participatory observation, simak (listening), and in-depth interviews $[16,17]$. Data analysis used categorical and distributional methods, especially for direct elements (bagi unsur langsung or BUL) [18, 19].

\section{Results and Discussion}

\subsection{Syntactic error}

In this section, the author will identify various kinds of syntactic errors, which include (1) incomplete sentences, (2) the use of words di mana 'where' are not correct, (3) construction of the preposition owner, (4) error in word order, (5) The use of the word yang is inappropriate, (6) the sentence without subject, (7) the sentence has no object, (7) errors in the use of conjunctions and prepositions.

\subsubsection{Incomplete sentences}

The sentences below are examples of the use of sentences by Darmasiswa learning participants with the wrong word choice. The two sentences in the following example must be combined into one sentence because the first sentence contrasts with the second sentence. By combining these two sentences, the word again in the first sentence is omitted.

(1) Si suami bekerja di laut lagi. Tetapi dia tidak pulang ke rumahnya lagi. ('The husband is working at sea again. But he didn't come home anymore'.)

The sentence above can be corrected to

(1a) Si suami bekerja di laut, tetapi dia tidak pulang ke rumahnya lagi. ('The husband works in the sea, but he does not return to his house anymore'.)

\subsubsection{Use of the word di mana (Where) is inappropriate}

(2) Tempat ini menjadi musium yang dimana menyimpan gambar-gambar dan peninggalan pahlawan. ('This place is a museum which stores pictures and relics of heroes'). In example (2) above, use di mana 'whichever' size is not appropriate. The usage di mana (which) in the example must be omitted. So, the correction of the sentence above is as follows. 
(2a) Tempat ini menjadi musium yang menyimpan gambar-gambar dan peninggalan pahlawan. 'This is a museum that houses images and relics of heroes'.)

\subsubsection{Construction of preposition owner}

(3) Pemaes, dukun pengantin perempuan menjadi pemimpin dari acara pernikahan. ('Pemaes, the bride's dukun is the leader of the wedding ceremony'.)

(4) Di sini juga banyak dijual batik dari produk dari solo sendiri maupun daerah lain. ('Here also sold batik products from his own solo or in other regions'.)

The use of the word from which states the relationship between owner and possession in Indonesian is implicitly stated. In example (4) above, the owner-owned relationship is in the leader of the wedding ceremony. The word from the example must be removed so that it becomes the leader of the wedding ceremony. Whereas in example (5) there are two words from. $O f$ the former are owner-property relationships, while of the second state the origin. To be true (effective), the usewords of in the sentence should serve targeted diimplisitkan. The example above can be fixed to (3a) and (4a) as follows.

(3a) Pemaes, dukun pengantin perempuan menjadi pemimpin acara pernikahan. (Pemaes, the dukun bride takes charge of the wedding ceremony).

(4a) Di sini juga banyak dijual batik produk solo maupun daerah lain. (There are also many batik products sold in solo and other regions).

\subsubsection{Errors in word order}

(5) Pasar swalayan disukai semakin banyak karena kenyamanannya. ('Supermarkets are increasingly favored because of their convenience').

(6) Pada waktu yang paling panas, suhunya kadang-kadang mencapai naik 39 derajat C. ('At the hottest of times, the temperature sometimes rises to 39 degrees C'). The error in the examples above is a word order error. Example (5) is disukai semakin banyak 'preferred the more it' should be converted into semakin banyak disukai 'the more preferred'. In example (6) there is a construction 'mencapai naik' reaching rise supposed to naik mencapai 'rise reaching'. The improvement of the sentence above is as follows.

(5a) Pasar swalayan semakin disukai banyak karena kenyamanannya. ('Supermarkets are increasingly being favored because of their convenience).

(6a) Pada waktu yang paling panas, suhunya kadang-kadang naik mencapai 39 derajat $\mathrm{C}$. ('At the hottest time, the temperature sometimes rises to 39 degrees C').

\subsubsection{The use of the word yang is inappropriate}

(7) Tempat umum adalah tempat yang orang-orang berkumpul untuk melakukan suatu kegiatan. ('A public place is a place where people gather to carry out an activity'). The use of the word yang in the above example is not quite right. The word is not required in the sentence. So, the sentence above can be changed to

(7a) Tempat umum adalah tempat orang-orang berkumpul untuk melakukan suatu kegiatan. ('A public place is a place where people gather to do an activity').

\subsubsection{Sentences without subjects}

(8) Di taman depan kraton ramai sekali. ('The garden in front of the palace is very busy'). 
(9) Dalam kebudayaan Jawa terdapat beberapa proses sebelum melangsungkan pernikahan. ('In Javanese culture, there are several processes before getting married'). This type of error is a no subject sentence. The sentence above is preceded by a preposition in and in. The subject of a sentence which is preceded by a preposition causes the sentence to lose its subject. Sentence (8) can be corrected by omitting the preposition di. Example (9) improved by replacing the active form words melangsungkan 'carry' into the passive form dilangsungkan 'held'. So, fixing the example above becomes

(8a) Taman depan kraton ramai sekali. ('The front garden of the palace is very busy').

(9a) Dalam kebudayaan Jawa terdapat beberapa proses sebelum dilangsungkan pernikahan. ('In Javanese culture there are several processes before a marriage takes place').

\subsubsection{Sentences without objects}

(10) Waktu dia memotong pegangan pisau tiba-tiba jatuh. ('When he cut the knife handle suddenly fell').

(11) Setelah mendengar, wajah si suami mendadak berubah. ('Upon hearing, the husband's face suddenly changed').

The sentence predicate (10) is a transitive verb so that it needs an object. Likewise, in example (11) mendengar 'hearing' is a transitive verb. So, the two sentences above can be fixed by adding objects like the following.

(10a) Waktu dia memotong tiba-tiba pegangan pisau jatuh. ('When he was cutting sugarcane, the handle of the knife suddenly fell off').

(11a) Setelah mendengar cerita itu, wajah si suami mendadak berubah. ('After hearing the story, the husband's face suddenly changed').

\subsection{Factors causing errors}

Various Various linguistic errors of foreign speakers in speaking Indonesian, especially at the syntactic level, are caused by several factors, namely (a) the influence of the mother tongue, (b) the limited repertoire of the students (learners), and (c) the lack of practice speaking and writing in Indonesian. The first cause is a common symptom of deep foreign speakers learning a second language. Each speaker has been constructed and conditioned by the mother tongue system or national language in conveying ideas, ideas, thoughts, and feelings through the actions of the language. This matter because each language has a different system. Moreover, European languages with an MD structure are the opposite of Indonesian, which has a DM structure and other habits reflected in the following language. When a person learns a second language, it is almost certain that the first's mother tongue or language will affect the second language's speech so that interference occurs, especially at the syntactic level. A student from Russia, for example, stated, "Permisi Pak, saya tidak dapat masuk ini hari karena sedang ikut summer class di Jepara" 'Excuse me, Sir, I cannot enter today because I am participating in a summer class in Jepara'. This phrase ini hari (today) in the speech above influences the learner's usual mother tongue use the mother tongue in the MD structure. The structure of the phrase in Indonesian is hari ini.

The mistake of foreign speakers in learning other Indonesians is due to the limited repertoire or learner vocabulary. When people have limited vocabulary mastery, certain words are often used because speakers do not know the proper vocabulary to express the intended meaning/concept. The following statement shows the situation, "Maaf saya terlambat, berangkat dari kampus jam 11'. 'Sorry, I am late, leaving campus at 11'. Said berangkat 'depart' in the speech should go home. So, the correct speech is "Maaf saya terlambat, pulang dari kampus jam 11". 'Sorry I am late, come back from campus at 11 o'clock. 
The linguistic error of foreign speakers in speaking Indonesian is caused by a lack of practice speaking and writing in Indonesian. They generally prefer to use English among themselves learners who come from different countries. Communicating with fellow learners from the same country will use their language (mother tongue or national language). Moreover, the placement of more students is often dominated by certain countries, so that they use their mother tongue or national language more often than Indonesian.

\section{Conclusion}

Based on the results of the study found a syntax error in the form of a sentence is not completed, the use of the word where it is not appropriate, the construction owner said before, the use of the yang, the error sequence of words, sentences without a subject, sentences without an object, misuse of conjunctions and prepositions, improper use of the passive voice or active, foreign language interference, and misuse of pronouns. The factors causing the error are (a) the influence of the mother tongue, (b) the limited repertoire of students (learners), and (c) lack of practice in speaking and writing in Indonesian. To overcome these obstacles, a curriculum design is needed that emphasizes language or communication skills. Therefore, the curriculum design needs to be accompanied by a Semester Learning Plan (RPS) for all learning subjects along with textbooks and the learning methods used are emphasized on communication skills. In addition, to anticipate that participants from certain countries and institutions of origin are not concentrated in one university, the government, in this case, the Bureau of Foreign Cooperation, must re-evaluate the placement of student participants so that they are distributed evenly in various universities so that when in dormitories or boarding houses. does not always use the national language.

\section{References}

1. Ministery Of National Educaton, Clossing Address by HE Minister of National Education at the Closing Ceremony of the 2008/2009, Darmasiswa Program, (2009)

2. Wawancara dengan Moh.Muzakka, Ketua APPBIPA Provinsi Jawa Tengah, 15 Mei 2020

3. Basuki dalam www.google.com/pengajaran/bahasa.

4. J. Norish, Language Learners and Theirs Errors. (The Macmillan Press London, 1983)

5. S. Munawarah, Kesalahan Penulisan yang Dilakukan Penutur Asing dalam Belajar Bahasa Indonesia, Konferensi Internasional II Pengajaran Bahasa Indonesia bagi Penutur Asing (KIPBIPA II) IKIP Padang, (1996)

6. S. Dardjowidjojo, Masalah dalam Pengajaran Bahasa Indonesia sebagai Bahasa Asing di Indonesia, Kongres Internasional Pengajaran Bahasa Indonesia untuk Penutur Asing, 28-30 Agustus, Universitas Indonesia, Jakarta, 1995)

7. E. A. Indrariani, Perilaku Verbal antara Dosen dan Mahasiswa Asing dalam Interaksi Pembelajaran Bahasa Indonesia, Skripsi untuk Meraih Gelar Sarjana di Fakultas Ilmu Budaya Universitas Diponegoro Semarang, 2008

8. R. M. Wibowo, Kajian Perbandingan Pengajaran Bahasa Indonesia bagi Penutur Asing (BIPA) di Yogyakarta, Makalah disajikan dalam Seminar Pekan Ilmiah Bahasa dan Sastra Indonesia XXVII di Fakultas Bahasa dan Seni UNY Yogyakarta, (2005)

9. R. Noortyani, Buku Ajar Sintaksis, (Penebar Pustaka Media Yogyakarta, 2017)

10. M. Ramlan, Sintaksis, (Gadjah Mada University Press, 1985)

11. J. Santoso, Sintaksis Bahasa Indonesia, (Universitas Terbuka Jakarta, 2014) 
12. Supriyadi, Sintaksis Bahasa Indonesia, (UNG Press Gorontalo, 2014)

13. H. Kridalaksana, Beberapa Prinsip Perpaduan Leksem dalam Bahasa Indonesia, (Kanisius Yogyakarta, 1998)

14. N. A. Manaf, Sintaksis: Teori dan Terapannya dalam Bahasa Indonesia, (Pusat Pembinaan dan Pengembangan Bahasa Depdikbud Jakarta, 2009)

15. S. S. T. W. Sasangka, Kalimat. (Pusat Pembinaan dan Pengembangan Bahasa Kemdikbud Jakarta, 2014)

16. Sugiyono, Metode Penelitian Bisnis, (Alfabeta Bandung, 2012)

17. Sudaryanto, Metode Linguistik: Bagian II Metode dan Aneka Teknik Pengumpulan Data, (Gadjah Mada University Press Yogyakarta, 1988)

18. Sudaryanto, Metode dan Aneka Teknik Analisis Bahasa, (MLI Komisariat UGM Yogyakarta, 1985)

19. T. M. J. Kesuma, Pengantar (Metode) Penelitian Bahasa, (Carasvatibooks Yogyakarta, 2007) 